\title{
LOCALIZATION BASED DYNAMICS IN THE RENEWABLE ENERGY SECTOR
}

\author{
DOI: 10.17261/Pressacademia.2019.1037 \\ JMML- V.6-ISS.2-2019(4)-p.95-102
}

\section{Anil Serifsoy ${ }^{1}$, Murat Ferman ${ }^{2}$}

${ }^{1}$ şıı University, Maslak Campus, Istanbul, Turkey.

anilserifsoy@gmail.com ORCID: 0000-0002-7930-8045

${ }^{2}$ Beykent University, Maslak, Istanbul, Turkey.

muratferman@beykent.edu.tr ORCID: 0000-0003-4019-0219

Date Received: May 1, 2019

Date Accepted: June 19, 2019

To cite this document

Serifsoy, A., Ferman, M. (2019). Localization based dynamics in the renewable energy sector. Journal of Management, Marketing and Logistics (JMML), V.6(2), p.95-102, DOI: 10.17261/Pressacademia.2019.1037

Permemant link to this document: http://doi.org/10.17261/Pressacademia.2019.1037

Copyright: Published by PressAcademia and limited licenced re-use rights only.

\section{ABSTRACT}

Purpose - This paper examines the upwards trend of utilizing localization as a strategy by Multinational Enterprises in the energy sector. It is a sector that is driven by the governments, due to the ever-growing need for survivability and sustainability in a world increasingly dependent on energy.

Methodology - In-depth interview is the chosen method to obtain the critical opinions of small number of respondents who play a crucial role for decision-making in a leading company that prefers to utilize localization. This data is collated into a content analysis to determine the factors influencing it.

Findings- Localization from a global company engaging in renewable energy sector can be desirable, and indeed, profitable, insomuch as the right conditions outlined by the interviewees are created.

Conclusion- It is the intent of the author to build the first step of a guide to attract more positive attention from MNEs to encourage more technology transfer.

Keywords: Renewable energy, multinational corporation strategies, localization, government policies JEL Codes: M38, F13, P28

\section{INTRODUCTION}

Globalization strategy has been one of the most important strategies of the Multinational Enterprises (henceforth MNEs) for years. The term international strategy has been more concerned with the article of "The Globalization of Markets" by Theodore Levitt. Thodore Levitt, who coined the term globalization (Feder, 2006), explains the importance of the global strategies that should be applied by the MNEs focusing on the permanent growth. "Which strategy is better is not a matter of opinion but of necessity" (Levitt, 1983). Albeit not easy to implement, these strategies are vital enough for these MNEs to take the risk and spend their resources to improve their financial and non-financial conditions or even for survival in the harsh market environment. With the help of easier international business and less economic obstacles between the countries let MNEs that aimed higher expand their potential markets and allowed them to have more profit by not only making business in their own country but also worldwide. According to Sachs Goldman (2003) and Vaclav (2012) emerging markets such as BRIC countries would become more attractive for the MNEs located in developed markets. With the "expanding consumer bases, rising income level and gradual opening to global trade" the MNEs provide a better potential and guarantee their future successes (Maha , Ignat, \& Maha , 2010). Along with this strategy, the great benefits provided with the localization make it more attractive and applicable for the MNEs. It has been argued that companies should emphasize localization strategies because adaptation to 
local norms is essential for the success of a new subsidiary, and in this context numerous benefits have been attributed to localization in its various forms (Johri \& Petison, 2008). Utilizing localization as a strategy has increased especially in the energy sector, due to the ever-growing need for survivability and sustainability. Energy is defined as something essential that cannot be substituted. With the developing technology and its irreplaceable products which causes all of us to dependent on them, energy becomes more essential every day. It has turned into a vital element that is impossible to survive in the absence of it. Therefore, governments have started to take energy needs into consideration when planning for the future and finding local sources of energy as well as managing them became a priority in this context (Pamir, 2005). Hence, to provide the required level of energy, not only MNEs but also governments have been working on the localization process for their energy needs. Following this framework, renewable energy production is a new trend to provide a clean and sustainable energy. It appeals to both the governments and entrepreneurs with a shorter pay-back time and longer lifetime of the investments, grabbing the attention of private and governmental sectors alike (Serifsoy, 2019). This article aims to be an exploratory study that showcases the dynamics of the localization strategy on the renewable energy sector. The MNEs' strategies on the localization front will be examined through one of the more well-known companies in the sector; ABB. Its approach to localization in renewable energy sector and the governmental actions to prompt these responses will be highlighted. ABB as a company has had a long history in electrification and various other forms of energy production, as well as a documented preference for localization where it is possible, company interests permitting.

There are two different phases for the conducting of the research. The first phase is collecting all the necessary information about the energy market of Turkey and the governmental position on the renewable energy with relevant policies. Primary and secondary data is used in this stage to set the correct data. In the second stage, ABB is evaluated to ascertain how willing it is to comply with localization strategy in a new and developing market; Turkey having been selected as the case study. ABB executives who are directly involved and one of the determinants to achieve the success for the adaptation of the localization in the renewable energy market in Turkey, are interviewed to accomplish this objective. In-depth interview is the chosen method to get the critical opinions and the perspective of the small number of respondents who play a critical role for the determination of the strategy of the aforementioned MNE. This data is collated into a content analysis to determine the behavior of a giant in energy sector regarding localization. Also its counterpart, in this case the government, is examined as far as its behavior to ensure that localization occurs. As ABB's inner dynamics when countered with the Turkish government's approach regarding localization of renewable energy is examined in Serifsoy's dissertation, one point remains partially incomplete: governmental predictions for attracting investment from MNEs.

This article highlights the actions for the governments to consider the steps that need to be taken to secure foreign investments coming through MNEs. Traditionally, governments offer incentives and tariffs to secure a MNEs interest in building plants and producing with locally sourced materials, immaterial of the sector. In renewable energy sector, through shedding light on the actions of $A B B$ in regard to localization on this matter, this article is intended to be the first step of a guide for the government to take appropriate actions in the future concerning the particular matter of localization in renewable energy sector. While creating new regulations such as YEKA, understanding the preferences of MNEs and tailoring the incentives accordingly would, no doubt, bring forth more of the investment that is aimed through these programs.

\section{DATA AND METHODOLOGY}

With an inductive approach, the article aims to clarify the dynamics of the localization from different sources with different experiences. The strategy to have the data includes both primary and secondary. With the secondary data, the literature will be reviewed to get initial knowledge not only about the strategy but also about the market and the sector. The strategy that is used to get all the necessary data is determined as interview to get it from the primary sources. The most essential information is taken from the managers of a global company that experiences the localization strategy in many ways. Due to the limitation of the dedicated managers who play an active role in the decision-making stage of the localization strategy of the selected MNE, unstructured in-depth interview plays an important role to get all that essential information in detail. As it is mentioned in the Research Onion (Saunders, Lewis, \& Thornhill, 2009), strategy should be defined to collect the required data. As it is an inductive study and the main aim is to create an exploratory research, survey is a good way to collect the data from the primary sources in detail. A structured short question and answer survey is not fully suitable to get all the information on this topic, because the main aim is to clarify the path of the localization strategy in renewable energy market and provide inductive approach. Unstructured interview is generally used for the exploratory studies to get more detailed information instead of receiving short answers for the same questions. Instead of the quantity of the informants, quality matters to get the correct information. The information is taken from the experienced informants by asking the questions according to the answers. Even though the main 
idea underneath the questions are similar, they vary. Although the interview is unstructured, and it needs to be like a face to face conversation, some processes should be covered in advance.

The in-depth interviews that were conducted with the aforementioned managers occupying both global and local positions in ABB, as well as a governmental employee of Turkish Republic, are collated into Tables 1 through 3 that are displayed below. These executives are selected for the interviews due to the positions they occupy in ABB hierarchy, both on a local and on a global level. Of the seven executives that are interviewed, all of them have localization experience on multiple levels on multiple fronts. The executives that report to a global level, explored as a section, have experiences that encompass multiple countries, such as Brazil and China, in their efforts of localization in renewable energy sector. Therefore, for them to analyze the compare Turkey's policies that of the other countries' in this sector is a crucial part of the article. It is one of the points that this article aims to prove that if the government indeed is looking for localization in the renewable energy sector; consequently, technology transfer, there are steps that need to be taken in accordance with these executives' vast experiences in other countries in relevant positions. Tables 1 through 3 display the data gathered from the interviews to build the basis for later content analysis. In these tables, the information on the interviewees, such as their attitude towards renewable energy or what they consider success factors for strategies they applied in renewable energy sector are put into a matrix. These tables later on are turned into a seven part content analysis. The content collected from these interviews is divided into seven different categories across every interviewee with two sub-groups for each category in order to acquire a clear picture as to their concept of localization in renewable energy industry and in turn, as to how necessary they consider it is (Erlingsson \& Brysiewicz, 2017). The implications inferred from each interview are gathered using the answers the interviewees have for the questions, defined in Appendix A, and the points they intersected are highlighted throughout this section using the categories as a template to formulate upon. In each category, the interviewees are divided into the sub-categories according to certain facts that have in common (e.g. the type of engineering degree each interviewee has, whether or not they are Turkish citizens, or the level of reporting they do in their respective organizations) as well as what can be inferred as common ground according to the answers they come up with to same type of questions that are indicative of their mindsets and the relative levels they occupy in management. The following parts explains in detail of all the seven categories and each sub category that they contain.

Table 1: Summary of Semi-Structured in-depth Interviews

\begin{tabular}{|c|c|c|c|c|}
\hline INTERVIEWEES & $\begin{array}{c}\text { Summery of renevera ble energy izue (why, how ond how much) } \\
\text { regerding the world and ppecifically Turkey }\end{array}$ & Attitude towa rds reneva ble energy use & $\begin{array}{c}\text { Strotegy of the governm ents for reneus be energy (tarifts, } \\
\text { incentive snd projects) }\end{array}$ & Renewable energy snd localization stretegy \\
\hline AŬ BŪLENT KAPÇI & $\begin{array}{l}\text { World: Clean } \\
\text { Turkey: Better Poce, Following the technology, loca ization }\end{array}$ & $\begin{array}{l}\text { World: Incressing trend due to the cles nliness } \\
\text { Turkey: Updating the 2023 target } \text { bey ond the estimation } \\
\text { P3 }\end{array}$ & $\begin{array}{c}\text { Projects (Yda) } \\
\text { Che nge in Tariffs } \\
\text { Local Content } \\
\text { P4P7, P11 }\end{array}$ & $\begin{array}{l}\text { Technology Tanster } \\
\text { P\&Pg }\end{array}$ \\
\hline SAMISEVINÇ & $\begin{array}{c}\text { Decresese of the production costs increseses the usage } \\
\text { Oles nlines } \\
\text { Sustainable energy, Continuity } \\
\text { P3.P4 }\end{array}$ & $\begin{array}{l}\text { World: clesnlinez } \\
\text { Turkey: prefer cles nlines insteed of price? } \\
\text { P4 }\end{array}$ & $\begin{array}{l}\text { USA's strategy in } 1970 \\
\text { YEKA (Negetive) } \\
\text { P5 P6 }\end{array}$ & $\begin{array}{c}\text { Technology sted ling insteded d technology transfer } \\
\mathrm{pg}\end{array}$ \\
\hline TANER TEZCAN & $\begin{array}{l}\text { Growing trend } \\
\text { P3 }\end{array}$ & $\begin{array}{l}\text { Fest Folower } \\
\text { P3-p4 }\end{array}$ & $\begin{array}{l}\text { Local Content } \\
\text { Teriffs } \\
\text { Yeks } \\
\text { P4P5-P6 }\end{array}$ & $\begin{array}{l}\text { Technology Tanster } \\
\qquad \mathrm{PG}\end{array}$ \\
\hline TAMER KUZGUNKKAYA & $\begin{array}{l}\text { Growing trend } \\
\text { Environmental conscious } \\
\text { Kyoto Protocol } \\
\text { P2-P3, P4 } \\
\end{array}$ & $\begin{array}{l}\text { Weath and Technology drive the reneva ble energy sector } \\
\qquad \text { Emissions Level } \\
\text { P4 }\end{array}$ & $\begin{array}{l}\text { Renewa ble energy sould be focused if the country doesnt } \\
\text { have the required oil resenes } \\
P 6\end{array}$ & $\begin{array}{l}\text { Producing continuous energy } \\
\text { Producing own technlogy } \\
\text { P6 }\end{array}$ \\
\hline EREN AYDN & $\begin{array}{l}\text { Locational advantege } \\
\text { Increse sing pece with captured technology } \\
\text { Clesnines } \\
\text { P3.p4 }\end{array}$ & $\begin{array}{l}\text { Politcal izue incress } z \text { the usge of reneve ble eneggy } \\
\qquad P 5\end{array}$ & $\begin{array}{l}\text { Teriffts } \\
\text { Yeks } \\
\text { P6 P8 }\end{array}$ & $\begin{array}{c}\text { not able to produce its own reneable energy with the } \\
\text { trensiferred technology } \\
\text { Lack of R\&D Knowiedge } \\
\text { P7.PB }\end{array}$ \\
\hline ROBERT REINIUS & $\begin{array}{l}\text { Huge potential but storege problems } \\
\qquad \text { P3 }\end{array}$ & $\begin{array}{l}\text { Weath and Technology drive the reneva ble energy sector } \\
\qquad P 3\end{array}$ & $\begin{array}{l}\text { Free Market: The technology wil be more developed and } \\
\text { more adapted to the local conditions } \\
\text { P5 }\end{array}$ & $\begin{array}{l}\text { Sutainable em ploym ent and work for people } \\
\qquad \text { P6 }\end{array}$ \\
\hline TONI TIIHONEN & $\begin{array}{l}\text { Clesnines } \\
\text { P3 }\end{array}$ & $\begin{array}{l}\text { Paris Agreement } \\
\text { Energy Mix } \\
\qquad 33\end{array}$ & $\begin{array}{l}\text { Teriffs } \\
\text { Yeks } \\
\text { P5 }\end{array}$ & $\begin{array}{l}\text { Free Market } \\
\text { ottract the investors } \\
\qquad 66\end{array}$ \\
\hline RAIMO SAKKI & $\begin{array}{l}\text { Potential } \\
\text { P3 }\end{array}$ & $\begin{array}{l}\text { People's mind change. } \\
\text { Solar vs Wind } \\
\text { P4.PS }\end{array}$ & $\begin{array}{l}\text { Smarter way of the government to make more open } \\
\text { competition. } \\
\text { P9P10 }\end{array}$ & $\begin{array}{l}\text { IKEA Model, Local com ponents } \\
\text { P1OP11 }\end{array}$ \\
\hline
\end{tabular}




\section{Table 2: Summary of Semi-Structured in-depth Interviews}

\begin{tabular}{|c|c|c|c|c|}
\hline INTERVIEWEES & ABB's approach to renewable energy issue & $\begin{array}{c}\text { ABB's approach to localization strategy regarding } \\
\text { renewable energy }\end{array}$ & $\begin{array}{l}\text { Positive and neg ative consequences of } \\
\text { localization strategy }\end{array}$ & Measure of success factors \\
\hline ALI BÜLENT KAPÇI & $\begin{array}{l}\text { One of the two companies } \\
\text { P6 }\end{array}$ & $\begin{array}{l}\text { One of the greatest power which is able to achieve } \\
\qquad \mathrm{PG}\end{array}$ & $\begin{array}{l}\text { Creating local brands that has the technology } \\
\qquad \text { P2, P8 }\end{array}$ & $\begin{array}{l}\text { Creating local brands that has the technology } \\
\qquad \text { P2, P8 }\end{array}$ \\
\hline SAMI SEVINÇ & $\begin{array}{l}\text { Huge product renage that is suitable for } \\
\text { renewable energy } \\
\text { P10 }\end{array}$ & $\begin{array}{c}\text { focused } \\
\text { P11 }\end{array}$ & $\begin{array}{l}\text { Feasability } \\
\text { P12 }\end{array}$ & $\begin{array}{l}\text { Strategy of the govemment } \\
\text { P12-P13 }\end{array}$ \\
\hline TANER TEZCAN & $\begin{array}{l}\text { Focusing on the localization to produce good } \\
\text { quality products to lower prices } \\
\qquad \text { P6 }\end{array}$ & $\begin{array}{l}\text { Similar attempts from ABB } \\
\qquad \text { 66-P7 }\end{array}$ & $\begin{array}{c}\text { Labor force } \\
\text { Technology Transfer } \\
\text { export potential } \\
\text { P\&-pg }\end{array}$ & $\begin{array}{l}\text { Technology transfer } \\
\text { P9 }\end{array}$ \\
\hline TAMER KUZGUNKAYA & ABB's manner toward the environment & $\begin{array}{l}\text { Supportive } \\
\text { Feasibility } \\
\text { P7-P8 }\end{array}$ & $\begin{array}{l}\text { Investment, and the risks } \\
\text { P9-P10 }\end{array}$ & $\begin{array}{l}\text { transferring the technology that allows } \\
\text { production in ABB Standarts } \\
\text { P10-P11 }\end{array}$ \\
\hline EREN AYDIN & $\begin{array}{l}\text { Thinking globally acting locally } \\
\qquad P 9\end{array}$ & $\begin{array}{c}\text { Supportive, shareing all the information and know- } \\
\text { how } \\
\text { P9 }\end{array}$ & $\begin{array}{l}\text { Positive } \\
\text { P10-P12 }\end{array}$ & $\begin{array}{l}\text { Continuity of the sales, } \\
\text { Sustainable development } \\
\text { P13-14 }\end{array}$ \\
\hline ROBERT REINIUS & $\begin{array}{l}\text { Mobile Test Bench } \\
\qquad \text { P7 }\end{array}$ & $\begin{array}{l}\text { Similar attempts from ABB } \\
\qquad 88\end{array}$ & $\begin{array}{l}\text { Market Entry } \\
\text { Risks } \\
\text { P9 }\end{array}$ & $\begin{array}{l}\text { Overall profitability and that consists of cost of } \\
\text { the save } \\
\text { P9 }\end{array}$ \\
\hline TONI TIIHONEN & $\begin{array}{c}\text { feasability } \\
\text { P7 }\end{array}$ & $\begin{array}{c}\text { to overcome high taxes, bureaucracy and general } \\
\text { high interest rates } \\
\text { P7-pg }\end{array}$ & Acting locally but finalizing all the project in global & $\begin{array}{l}\text { feasbility, suitability } \\
\text { P10 }\end{array}$ \\
\hline RAIMO SАКKі & $\begin{array}{l}\text { Partnership requires more commitment } \\
\text { Creating own competitor } \\
\text { So careful } \\
\text { P14 }\end{array}$ & $\begin{array}{c}\text { Careful } \\
\text { Similar attempts } \\
\text { P15 }\end{array}$ & $\begin{array}{l}\text { Creating own competitor } \\
\text { Not to harm the quality not to harm brand } \\
\text { P14-P16 }\end{array}$ & $\begin{array}{l}\text { Knowledge of people } \\
\text { Understand the process } \\
\text { P15-P18 }\end{array}$ \\
\hline
\end{tabular}


Table 3: Summary of Semi-Structured in-depth Interviews

\begin{tabular}{|c|c|c|c|}
\hline INTERVIEWEES & $\begin{array}{l}\text { Difficulties and obstacles loca lization strategy } \\
\text { faces }\end{array}$ & $\begin{array}{l}\text { Recipe of success for MNEs regarding the } \\
\text { application of localization strategy in renewable }\end{array}$ & $\begin{array}{l}\text { Suggestions for successful future endeavors } \\
\text { for ABB }\end{array}$ \\
\hline ALI BÜLENT KAPÇI & $\begin{array}{l}\text { Raw materials } \\
\text { Certification } \\
\text { P15,P18 }\end{array}$ & $\begin{array}{c}\text { Step by step growth ( localization, global brand) } \\
\text { P19 }\end{array}$ & \\
\hline SAMI SEVINÇ & $\begin{array}{l}\text { Raw Materials } \\
\text { P14 }\end{array}$ & $\begin{array}{l}\text { Financially Feasability } \\
\text { P15-P16 }\end{array}$ & $\begin{array}{l}\text { Local Production if it is feasble } \\
\qquad \text { P17 }\end{array}$ \\
\hline TANER TEZCAN & $\begin{array}{l}\text { Uncertainity about govemment stragies } \\
\text { P10-P11 }\end{array}$ & $\begin{array}{l}\text { First movers get the market } \\
\text { Correct Strategy } \\
\text { P11-12 }\end{array}$ & $\begin{array}{l}\text { Localized production brings competition that } \\
\text { increases the quality lowers the prices } \\
\text { P6 }\end{array}$ \\
\hline TAMER KUZGUNKAYA & $\begin{array}{c}\text { Bureaucracy } \\
\text { Convincing the decision makers } \\
\text { Qualified labor force } \\
\text { P11 }\end{array}$ & $\begin{array}{l}\text { Technology transfer and increasing the know how } \\
\text { P10-P11 }\end{array}$ & \\
\hline EREN AYDIN & $\begin{array}{l}\text { Lack of knowledge in Turkey } \\
\text { Qualified labor force } \\
\text { P14-P15 }\end{array}$ & $\begin{array}{l}\text { Strategic movement } \\
\text { P15-P16 }\end{array}$ & \\
\hline ROBERT REINIUS & $\begin{array}{l}\text { Production and local business } \\
\text { P10-P11 }\end{array}$ & $\begin{array}{l}\text { competence and commitment } \\
\text { P11 }\end{array}$ & $\begin{array}{l}\text { PG (product group) level understanding of } \\
\text { localisation } \\
\text { P11 }\end{array}$ \\
\hline TONI TIIHONEN & $\begin{array}{l}\text { The lack of skilful people } \\
\text { Learning process } \\
\text { P12 }\end{array}$ & $\begin{array}{l}\text { long term cooperation is needed for the success } \\
\text { of ABB } \\
\text { P13 }\end{array}$ & $\begin{array}{l}\text { Development of the products } \\
\text { Lower costs and better productivity } \\
\text { P14 }\end{array}$ \\
\hline RAIMO SAKKI & $\begin{array}{l}\text { Protecting the quality } \\
\text { P16-P18 }\end{array}$ & $\begin{array}{c}\text { feasibility } \\
\text { Know-How } \\
\text { Precess knowledge } \\
\text { P16-P18 }\end{array}$ & $\begin{array}{l}\text { Market driven sector } \\
\text { Risk analysis }\end{array}$ \\
\hline
\end{tabular}

\section{FINDINGS AND DISCUSSIONS}

The in-depth interviews that were conducted with the aforementioned managers occupying both global and local positions in $A B B$, as well as a governmental employee, are collated into the table that is displayed below. The content is divided into seven different categories across every interviewee with two sub-groups for each category in order to acquire a clear picture as to their concept of localization in renewable energy industry and in turn, as to how necessary they consider it is. Table 4 displays these seven categories in a matrix, using the data gathered from the interviews and collated into the Tables 1 through 3 . The categories described in the Table 4 are explained in detail in the discussion sections below. 
Table 4: Classification of Content Analysis

\begin{tabular}{|c|c|c|c|c|c|c|c|c|c|c|c|c|c|c|c|}
\hline \multirow{2}{*}{ INTERVEWESS } & \multicolumn{2}{|l|}{1} & & & & & \multicolumn{2}{|c|}{4} & \multicolumn{2}{|r|}{5} & \multicolumn{2}{|c|}{-6} & \multicolumn{2}{|r|}{7} & \multirow{2}{*}{ Localzation } \\
\hline & Aectrocal evig & OTHES & QOBAL LVVE & LOCALVVE & ForeGt & 106 & COV.EMPLOYY & Lese EnP & HIG LVE & MEOUM IEVELI & TECHNCaL MnOSE & MANUCERaL MIIOSE & REIEWQBLI: & Now-Febiwable & \\
\hline ALi QÜLENT KAPÇI & $\sqrt{ }$ & & & $\sqrt{ }$ & & $\sqrt{ }$ & $\sqrt{ }$ & & & $\sqrt{ }$ & & $\sqrt{ }$ & $\sqrt{ }$ & & $\sqrt{ }$ \\
\hline samis sviing & & $\sqrt{ }$ & $\sqrt{ }$ & & & $\sqrt{ }$ & & $\sqrt{ }$ & $\sqrt{ }$ & & & $\sqrt{ }$ & & $\sqrt{ }$ & $\sqrt{ }$ \\
\hline tanER TEZCAN & $\sqrt{ }$ & & & $\sqrt{ }$ & & $\sqrt{ }$ & & $\sqrt{ }$ & $\sqrt{ }$ & & $\sqrt{ }$ & & & $\sqrt{ }$ & $\sqrt{ }$ \\
\hline TAMER RURGUNAYY & $\sqrt{ }$ & & & $\sqrt{ }$ & & $\sqrt{ }$ & & $\sqrt{ }$ & & $\sqrt{ }$ & $\sqrt{ }$ & & & $\sqrt{ }$ & $\sqrt{ }$ \\
\hline EENA AYON & $\sqrt{ }$ & & & $\sqrt{ }$ & & $\sqrt{ }$ & & $\sqrt{ }$ & & $\sqrt{ }$ & $\sqrt{ }$ & & & $\sqrt{ }$ & $\sqrt{ }$ \\
\hline ROBERr resinus & & $\sqrt{ }$ & $\sqrt{ }$ & & $\sqrt{ }$ & & & $\sqrt{ }$ & $\sqrt{ }$ & & & $\sqrt{ }$ & & $\sqrt{ }$ & $\sqrt{ }$ \\
\hline TONI TiHONEN & & $\sqrt{ }$ & $\sqrt{ }$ & & $\sqrt{ }$ & & & $\sqrt{ }$ & & $\sqrt{ }$ & & $\sqrt{ }$ & $\sqrt{ }$ & & \\
\hline paimo sakxi & $\sqrt{ }$ & & $\sqrt{ }$ & & $\sqrt{ }$ & & & $\sqrt{ }$ & $\sqrt{ }$ & & & & $\sqrt{ }$ & & $x$ \\
\hline
\end{tabular}

\subsection{Schooling/Career Path}

The first category indicates the department the executives of $A B B$, and the government employee have studied in and specialized on. Although all engineers in trade, the managers interviewed differ in the departments they graduated from and the topics they pursued later in their career paths. There are five electrical and or electrical/electronical engineers among the interviewees, with three of them following other career paths such as a mechanical engineering specialization. When examined, the interviews conducted by the five electrical and or electrical/electronical engineers display a tendency to focus on the more technical side of the job and being concerned with the productivity along with the technical specifications of the renewable energy issues. They are also the ones that have a more in-depth insight into renewable energy types and appear to discuss the individual categories of wind, geothermal, solar, etc. energy more in detail. Of the three that have chosen to follow career paths other than electrical and/or electrical engineering display a readier broader focus on renewable energy in general, rather than the energy types and various technical focal points that inevitably arise.

\subsection{Level of Reporting}

The interviewees' level of reporting was chosen as the second category to analyze the date gathered in the in-depth interviews. Four of them work on a global scale rather than local, and as such, their primary reporting is done on a global basis. The other four have positions that place them firmly within a certain country's purview, in this case Turkey both for the ABB employees interviewed and the YEGEM one. The differences in the reporting levels also demonstrate the angle they could look at the various issues regarding localization question in renewable energy. The ones that work on a global level tend to look at the bigger picture, with a broader understanding about how bottom line needs to be maintained in a company, as well as being concerned about the potential losses that said company might suffer from in case of any mishaps regarding any technological transfers, which have happened before as it was outlined on the China example of localization on renewable energy by Sakki. In layperson's terms, one might even say that the managers that are positioned more globally and higher up the food chain as it were, have a less emotional outlook into losses and gains both for the country that localization would happen -in this case Turkey- and the company in question, which happens to be ABB. The managers that have more local positions, i.e. reporting to superiors still within the hierarchy of a specific country (in this case Turkey, such as Tezcan or Aydın) tend to have a perspective that supports technology transfer in order to have Turkey gain more in long term. With this in mind, they support localization outright for the development of highly technological products manufacturing as it will help the country to reach its industrial aims of becoming more independent with locally sourced and produced goods. 


\subsection{Nationality of The Interviewees}

The third category to be discussed in detail is whether these managers are Turkish or foreigners. This affects the approach to localization. Turkish people naturally have more at stake for benefact the country's industrialization process, while the foreigners gravitate to a more neutral perspective that favors whatever would help the company financially. So, if profitable, localization would be pursued by this category, and not just because it is seen as a good thing for Turkish industry. As opposed to this less emotional viewpoint, the Turkish managers in general (other than Sami Sevinç, who by the virtue of his more global position has a broader outlook into business) uniformly support the localization efforts.

\subsection{Place of Employment}

There are seven managers employed by ABB in the interview roster, while one interviewee is employed in a governmental institution. Kapçı, as a governmental employee, unilaterally is in favor of localization. In fact, none of the other interviewees' words on the topic rival his emphasizing of the issue. The ABB managers, in contrast, while in favor of localization to certain extent (depending on the other factors such as the global/local positioning on the company hierarchy) while still being concerned with the bottom line for the company and other financial constructs inherent in running a business. Also, technology transfer is still considered an issue by ABB managers, independent from the side of the line they stand regarding the situation. For instance, for Sakki, technology transfer presents a real complication in localization efforts; but remaining ABB managers, through different degrees, are cautiously optimistic or outright in favor of localization.

\subsection{Relative Levels of The Executives}

Another category is chosen as the level of the executives that conducted the interviews. While similar in nature to the second category, this one separates itself from the other categories by offering insight into the perspective of managers by examining their relative advancements in management. High level executives would have been thought to offer less support for localization, as they tend to look into matters more broadly and less emotionally, while more of a medium level executive would have been thought to have a more biased look due to not being able to see the bigger picture. The outliers here are Tiihonen and Tezcan, seemingly departing from the level in management and the correlation it has with the supporting of localization. A higher-level executive, Mr. Tezcan is firmly in the corner of the localization, while Tiihonen has more of a neutral outlook that cautiously supports it, as long as it does not interfere with the profitability of the company. These outliers could be linked to the nationalities of the men in question. As mentioned in the third category, the nationality tends to affect one's outlook into localization and its effects on the host country, whereas Tiihonen's being a global level manager effects his perspective of localization, as depicted in the second category.

\subsection{Mindset of Executives}

The sixth category shows the difference in thinking for the executives. The kind of mindset they have carry into their perspective on localization. The managers with more technical mindset, focusing more on the technical aspects of the renewable energy production as well as its types are equally divided in number with the ones that have more of a managerial mindset that necessitates a different response. Again, in this category Sakki appears to be an outlier, supporting localization less optimistically than the rest of the executives with technical mindset, which can be linked back to him being a foreigner and a global level executive more than anything else. As for Kapçı, despite being more managerial in his attitude than the rest, he fervently supports localization, which still is very much in tune with him being a government employee and his nationality.

\subsection{Focus on the Renewable Energy}

The last category to be discussed is the focus of the interviewees into renewable energy as a whole. While three executives have chosen renewable energy as a career path, five of them are still using their expertise on other fields as well and this reflects in their approach to the localization. The ones that focus on renewable energy exclusively have a narrower focus, resulting a corresponding narrower perspective. For them, it is more about the market and becoming a supplier for everyone than investing in a country as an individual company that has bids in the local renewable energy projects. The executives who have not followed renewable energy as a career path but are at the forefront of running parts of a company that does get involved in it have a broader vision regarding the topic. They are not just concerned with the sales but also government regulations, investment opportunities and energy politics. From careful review of the existing literature on the subject and the analysis conducted on the contents of the interviews, it can be inferred that localization is found beneficial for MNEs under right conditions. When it is implemented as intended, the strategy can bring immense benefit to a company, as it is considered by the executives of ABB. Nevertheless, it is conditional, not absolute, and does not have de facto set rules of application that can be 
implemented in every country by every company, hence the cautious but optimistic answer from most of the interviewees as "yes, if profitable". The conditions under which the profitability is achieved are covered in the sections for the categories the interviewees and their views are examined. While literature showcases that localization, when applied correctly, can bring out a lot of benefits; as a contrast, the executives interviewed have varied in their answers. While the ones that report on a local level have answered with a resounding yes, the global level executives employed a more cautious outlook and identified the special conditions where engaging in localization prove to be beneficial to their company. The factors that encourage the MNEs to apply localization strategy have been extensively reviewed in the literature. The benefits of a steady and loyal supply chain, cost cutting due to employing local personnel, the flexibility achieved with local R\&D are just but a few selected advantages that companies enjoy with well-applied localization strategy (Johri \& Petison, 2008). The analysis of the interview content, while supporting these findings, also cautions against the pitfalls of localization, such as the loss of valuable R\&D data and knowledgeable personnel via the inevitable technology transfer that Sakki emphasizes in his interview.

The disadvantages that localization brings about are a concern in regard to both the literature and the analysis of the interview content. The crucial points that the MNEs should be concerned with are clarified as the R\&D and personnel loss, as well as the expatriates that work for the local branches in a different country. These issues, by and large, are touched upon the interviewees with more managerial mindset and those who report at a global level. Government policies affect the localization process in renewable energy sector greatly. With the incentives governments offer to MNEs comes the opportunity to thrive as a company, but there are documented drawbacks if the localization process is not undertaken carefully, and it has the potential to harm the company in different ways. All the managers interviewed also have mentioned the government policies and how it shapes the efforts of the MNEs structure when penetrating the market.

\section{CONCLUSION}

Localization from a global company engaging in renewable energy sector can be desirable, and indeed, profitable, insomuch as the right conditions outlined by the interviewees are created. In which sphere the company operates is needed to be constructed carefully to create the right conditions under which a company penetrates a market and establishes dominance thereof. These considerations that are established in the article are meant to become a guide for the future governmental decisions that are taken to encourage localization in renewable energy sector. As pointed out extensively by the interviewees, the governments are concerned with ensuring localization in renewable energy sector for a variety of reasons, most of which are tied with the need to bring much needed technology transfer and boosting local economy with the added labor. In order to achieve this aim, governments have an obligation to create ideal conditions under which global companies operate; so that they consider investing locally in a country. The best way to achieve this is seen as bringing out tariffs and other capitulations a country may provide global companies. And while this approach has seen a considerable amount of success in Turkey, the new tariff policies that are to be crafted after 2020 should be more in tune with the needs and requirements of MNEs that operate in this sector. This article, in this way, is intended as a first step of a guide for the government for policy making. To be able to attract more investment from global companies in the renewable energy sector and encourage more technology transfer despite the misgivings regarding the issue, the government should be more amenable to the perspective presented by the global companies. This topic will benefit from more analysis pertaining to the relation between the government policies and the private sector perspective, and further studies can shed light on the outline that the author of this article intends for the policy making in renewable energy sector. 


\section{REFERENCES}

Ataseven, M. (2017, september 28). Rüzgâr Enerjisinin Geleceği ve YEKA. Türkiye Rüzgar Enerjisi Birliği.

Blazev, A. (2016). Global Energy Market Trends. The Fairmont Press, Inc.

Boyce, C., \& Neale, P. (2006). Conducting In-Depth Interviews: A Guide for Designing and Conducting In-Depth Interviews for Evaluation Input. Pathfinder International.

Demirbaş, A. (2001). Energy balance, energy sources, energy policy, future developments and energy investments in Turkey.

Index, p. 5.

Erlingsson, C., \& Brysiewicz, P. (2017). A hands-on Guide to Doing Content Analysis. ScienceDirect

Feder, B. J. (2006). Theodore Levitt, 81, Who Coined the Term 'Globalization', Is Dead. The New York Times.

Goldman, S. (2003). Dreaming with BRICs: The Path to 2050. Retrieved from http://www.goldmansachs.com/our-thinking/archive/bricsdream.html

GWEC. (2018, April). Global Wind Report. Annual Market Update.

İzgi, M. F. (2017, October). Renewable Energy Turkey. Retrieved from Renewable Energy Turkey: https://gettingthedealthrough.com/area/99/jurisdiction/54/renewable-energy-2018-turkey/

Johri, L. M., \& Petison, P. (2008). Value-based localization localization strategies automobile subsidiaries in Thailand. International Journal of Emerging Markets, 141.

Levitt, T. (1983). The Globalization of Markets. Harward Business Review.

Maha , L., Ignat, I., \& Maha, S. (2010). The impact of business localization on the international trade.

Pamir, N. (2005). "Enerji Politikaları ve Küresel Gelişmeler", Stratejik Analiz.

Saunders, M., Lewis, P., \& Thornhill, A. (2009). Research Methods for Business Students.

Serifsoy, A. (2019, June). An Explatory Study on the Dynamics of Localization of Renewable Energy Industry Among the Managers of a Leading Company . İstanbul, Turkey.

Vaclav, K. (2012). Seeking real causes of the European crisis. A Journal of Public Policy

\section{APPENDIX A: IN-DEPTH INTERVIEW PROTOCOL}

An Explatory Study on the Dynamics of Localization of Renewable Energy Industry Among the Managers of a Leading Company.

1) Acknowledgement for the participation

2) Introducing the interviewer

3) General information about the interviewee

4) Main purpose of the study

5) Note Taking / Taping permission

6) Summary of renewable energy issue (why, how and how much) regarding the world and specifically Turkey

7) Attitude towards renewable energy use

8) Strategy of the governments for renewable energy (tariffs, incentives and projects)

9) Renewable energy and localization strategy

10) $A B B$ 's approach to renewable energy issue

11) ABB's approach to localization strategy regarding renewable energy

12) Positive and negative consequences of localization strategy

13) Measure of success factors

14) Difficulties and obstacles localization strategy faces

15) Recipe of success for MNEs regarding the application of localization strategy in renewable energy Suggestions for successful future endeavors for $A B B$ 